\title{
Strategic Analysis of Synergistic Effect on M\&A of Volvo Car Corporation by Geely Automobile
}

\author{
Xia Zhou, Xiuzhi Zhang \\ School of Economic and Management, Jiangxi University of Science and Technology, Ganzhou, China. \\ Email: wymemory@163.com,leos_zhang@163.com
}

Received September $24^{\text {th }}$, 2010; revised October $25^{\text {th }}$, 2010; accepted November $7^{\text {th }}, 2010$.

\begin{abstract}
Strategic M\&A is focused on the development of enterprises within the same industry or related industries and has multiple effects such as economies of scale, structural integration of upstream and downstream industry chain, powerful alliances and complementary advantages. A major motivation of strategic M\&A is the synergistic effect. In the upsurge of M\&A at home and abroad, failed to achieve the synergistic effect is one of the important reasons of a high failure rate of M\&A. This paper probes into the example of Geely Automobile's M\&A of Swedish Volvo Car Corporation in March 2010 from a strategic angle by analyzing the strategic decision-making, the competitive environment, the mechanism of action, the evaluation and the realization risks of the synergistic effect, thus to provide references for the M\&A practice of Chinese enterprises.
\end{abstract}

Keywords: Strategic Perspective, M\&A, Synergistic Effect

\section{Introduction}

Strategic M\&A is a complex business involving great risk. Huge losses are often due to the errors in strategic decision-making. Understanding and evaluating the synergistic effect is very necessary for those companies which want to grow up through strategic M\&A, because it is not only the basis to determine the feasibility of M\&A, but also the basis for the set of transaction price, and to a extent, it determines the success or failure of strategic M\&A. At present, domestic M\&A activities are lack of the guidance of strategic thinking and the study of domestic scholars on synergistic effect from a strategic perspective are relatively less. In addition, M\&A activities of companies have high risks, according to the formula "M\&A synergistic effect = acquisition premium + the net present value of M\&A", even in the case of zero-premium, the companies still need to meet certain necessary competitive conditions as well as the basic requirements for synergistic effect, otherwise, the companies will be hard to avoid falling into the "synergy trap" $[1,2]$. Therefore, the main purpose of this paper is to make an analyze on strategic decision, competitive environment, mechanisms of action, the evaluation and realization risks of the synergistic effect from a strategic perspective, thus to provide references for Chinese companies to better achieve strategic M\&A synergies [3].
In recent years, China's automobile industry is very active in M\&A, this paper take Zhejiang Geely Holding Group's (hereinafter to be referred as Geely) M\&A of Sweden's Volvo Car Corporation(hereinafter to be referred as Volvo) for example to analyze M\&A synergies from a strategic perspective. Geely is a large-scale private enterprise of China which mainly produces motor vehicles and parts. Volvo was founded in 1927, which is one of the world's 20 largest automobile companies and enjoys high prestige in excellent quality and performance in northern Europe, especially known for its safety and environmental protection. At present, Volvo has nine series of automobile brands, three new intellectual property platform and more than 2,000 sales outlets worldwide. If Geely's M\&A of Volvo is successful, it will have historic direct effect to promoting the growth of China's automobile industry and change the pattern of future global automotive industry. Based on the above favorable considerations, Geely acquired $100 \%$ equity stake of Swedish Volvo in March 2010 successfully. This paper is appropriately amended as needed based on the original case.

\section{Strategic Decision Analysis of Synergistic Effect}

M\&A is a high-risk activity, great loss often springs from 
strategic decision mistakes, and therefore, the company's management must first clearly define the enterprise's development strategy and have to launch an investigation into the acquired enterprise's business and resources [4-6]. In the development of M\&A strategy, we can use some appropriate models to support M\&A decision such as BCG Matrix, PIMS methods and Directional Policy Matrix. The BCG matrix analysis of Geely's strategic M\&A can be represented as shown in Figure 1.

As Volvo is one of the world's 20 largest automobile companies, it has a huge market capacity and a relatively higher market increase rate. However, because of the global financial crisis in 2008, Volvo had huge losses last year due to poor management. In 2009, the total sales of Volvo was only 218.4 billion SEK (1 U.S. dollar equals 7.5 SEK), compared with 2008, its total sales reduced by nearly $30 \%$, which caused Volvo a huge loss of 14.7 billion SEK. Thus for Geely, Volvo belongs to the "Question marks" and can be indicated with solid line box in Figure 1. At this time, there need to input a large number of fixed capital and working capital. Geely should use appropriate means of financing to obtain sufficient funds to meet the growth of its market share. With regard to the capital source of Geely's M\&A of Volvo and the subsequent provision of huge working capital, the M\&A purchase price of Volvo is 1.8 billion dollars, plus follow-up liquid capital, Geely has prepared to provide a total of 2.7 billion dollars. Half of these funds were funded through domestic financing, the rest of the funds were foreign capital mainly coming from the United States, Europe and Hong Kong.

If the demand for Volvo's automobile continues to grow, after Geely's M\&A, Geely's production capacity will increase substantially and new Volvo production bases will be built at home. If Geely can be able to successfully solve the market digestive problems which caused by the excess production capacity, its relative market share will be greatly improved and the product will be gradually changed to the "Stars" and can be indicated with dotted box in Figure 1. At this time, the prod-

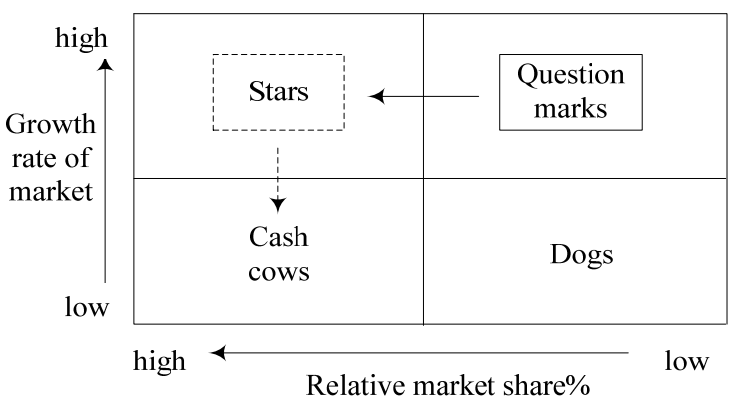

Figure 1. BCG matrix analysis of Geely automobile's strategic M\&A. uct may be advanced "absorber" or advanced "producer", which primarily depends on the amount of money needed to invest to maintain the market share. If the product can achieve a certain economies of scale, it will eventually change to "Cash cows" and Geely must ensure that its market share do not suffer erosion. Such strategic analysis tools will be conducive to make a more reasonable M\&A decision for Geely.

\section{Competitive Environment Analysis of Synergistic Effect}

According to Mark L Sirower's (1997) theory, "Synergistic effect" must be taken into account in the competitive environment $[7,8]$. M\&A must meet one of the following two points to achieve synergistic effect and obtain M\&A earnings. First, the acquirer must be able to restrict the competitive threat of the current and potential competitors in the input market, the production process or the output market; second, the acquirer must be able to open up new markets or invade and occupy the market of its competitors who can't react. Thus, before the analysis of M\&A synergies, we should first analyze the competitive environment of Geely. Competitive environment analysis of synergistic effect mainly includes two aspects: the analysis of industry barriers to entry and the analysis of competitive situation.

\subsection{Analysis of the Industry Barriers to Entry}

The industry barriers to entry can be analyzed from the need for capital, operating scale, technological content and cost disadvantages independent of scale, as shown in Figure 2.

\section{1) Fund demand.}

As for cost competitiveness, Geely's capacity planning is unavoidable and its capital cost will be higher and higher. As the automobile industry is capital-intensive industry, its $\mathrm{R} \& \mathrm{D}$ and the construction of production lines will face a high financial barrier. At present, Geely expands its production capacity in a "great leap forward" way, it has established production bases in Linhai, Zhejiang, Ningbo, Shanghai, Lanzhou, Xiangtan, Jinan, etc. According to Geely's current base construction development plan, by 2010, Geely's production capacity

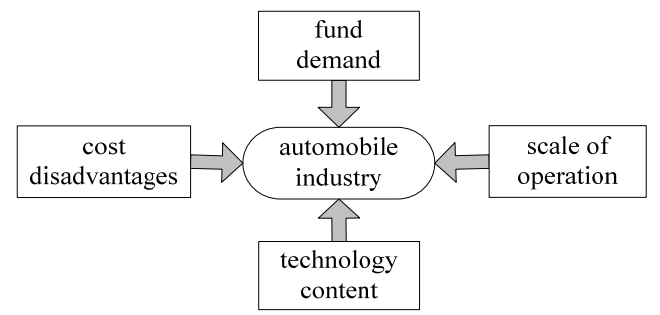

Figure 2. Analysis of automobile industry barriers to entry. 
will break 1 million vehicles and by 2015 reach 2 million. Relevant data show that in addition to 1.8 billion dollars of M\&A, Geely also need 1.5 billion dollars of liquid capital. The 1.8 billion dollars acquisition funds and the huge capital loans will certainly exert financial pressure on the operation of Geely.

2) Scale of operation.

Whether Geely can produce in large scale is a key factor in the success of its production. Because the automobile's R\&D costs are very high and there are appropriate costs of management, procurement and sales, Geely must produce in large scale, otherwise, the costs will be difficult to be amortized. After Geely's M\&A of Volvo, Geely will face numerous difficulties in product planning, site selection, the split with Chang'an Ford's products, whether the fund flow is smooth and the variables in the domestic market. These problems may lead to the failure of the M\&A in all probability. Geely's self-confidence seems to come from the infinite Chinese automobile market. Volvo has top 20 largest independent automobile parts suppliers, among them, 16 suppliers have set up factories in China. Through additional supporting factories in China, Geely is expected to reduce procurement costs at least 1.2 billion dollars within 5 years. However, to form a new plant, Geely need at least 1 and a half years, this should be the most difficult transition period after its M\&A of Volvo. Shufu Li, the president of Geely, who claimed that Volvo would be profitable in 2011 seems to be unbelievable.

3) Technological content.

Volvo is "the most secure vehicles" in the eyes of consumers. Through M\&A of Volvo, Geely can absorb Volvo's patented technology and expertise to enhance its technical strength and development capabilities, and at the same time to obtain fat profits of brand premium $[9,10]$. But the problem is that Geely's desire to acquire technology through M\&A may not realize. First, in order to protect their own interests, the host government, the acquired companies and its trade unions representing the interests of the parties may establish harsh restricted conditions of technology transfer and will carry out strict surveillance in the future; second, even if Geely obtain Volvo's technology at the best price successfully, this can not substitute its self-absorption and subsequent development. If Chinese companies can not form a sufficiently strong international competitiveness in technology development, Geely's plan to improve R\&D capacity through M\&A will likely come to nothing eventually. In 2004, SAIC Group spends 612 billion won (about 500 million dollars) in M\&A of 51\% equity stake of South Korea's fifth-largest car maker Ssangyong Motor. Afterwards, SAIC and Ssangyong union disputed many times, South Korean prosecutors also conducted a search of Korean headquarters of SAIC in the name of "leak core technology”. In the financial crisis, the continued loss of Ssangyong finally dragged down SAIC, in January 2009, SAIC filed for bankruptcy protection in Seoul District Court and give up the management of Ssangyong. Therefore, whether Geely can achieve bigger breakthrough on technology after M\&A will be difficult to identify.

4) Cost disadvantages independent of scale.

According to the strategy theory of Michael Baud, the acquired enterprises have cost advantages which were formed by means of experience accumulation and learning curve. But Chinese automotive industry operates by a way of high-cost, and there are still some barriers in getting the advanced experience. The factors of cost disadvantages independent of scale also include patent right, government subsidies and price inflation of equipment purchase which is caused by the changes in exchange rates. Geely have had overseas experience in restructuring and M\&A of British Manganese Bronze company and Australian DSI automatic transmission company, however, this time Geely mergered $100 \%$ equity stake of Volvo is a very huge project, including Volvo's $R \& D$ team, manufacture base, distribution channels, corporate debt and the reallocating of nearly 20,000 employees, this can not be compared with the previously M\&A of Manganese Bronze and DSI to Geely, who hasn't any experiences in manufacture and management of luxury vehicles, the cost disadvantages independent of scale is obvious.

From the above analysis we can see that there are high barriers to entry in automobile industry. Whether Geely can resist the pressure of competition and open up new markets depends on the strength of the industry's major competitors. This indicator can be measured by market share. From January to May in 2010, the sales of Volvo in China surged by $108 \%$ and led the luxury vehicles market. China has become the world's fourth largest market for Volvo. Globally, from January to April in 2010, the sales of Volvo increased by $26.5 \%$, which indicates that after M\&A, the growth of Volvo is not only weakened, but also obtains considerable progress. However, the current market in Europe has entered the drop period after spur growth, such situation will not conducive to Volvo's rapidly reduce losses and increase profits, and long-term depression may made Volvo more depreciatory, thus go against Geely's capital gain. With the recovery of the euro zone economy and the strength of U.S. dollar gradually winding down, the drop of the competitiveness of traditional industries in the euro area will exert a tremendous influence on Volvo's exports. The shrinking market is still the biggest problem to Geely's changing the fate of Volvo. 


\subsection{Analysis on the Competitive Situation within the Industry}

Although Geely is the industry leader in the domestic market, comparing with Japan, Germany and the United States, there is a considerable gap in its production technology, market capacity and innovation ability. Whether Geely can achieve synergistic effect through M\&A depends on its ability to get core competitiveness. Therefore, we need to analyze what factors constitute the company's core competencies and whether the companies can get core competitiveness through M\&A activities [11]. Factors of core competencies include the following aspects.

1) Determining the scope of business.

Experience in the industry shows that most of the major markets in the automotive industry are in a state of over-competition, the time that only rely on market growth to survive has passed. The first core competitiveness is how to determine the scope of business clearly and accurately.

2) Mastering the core technology.

The important features of the automotive industry are the ever-changing technology and its rapid upgrade. Enterprises which can not be unable to master core technology will be eliminated from the stage of international development.

3) The ability to attract and retain high-tech talents.

Automotive industry competition for talent is very intense and to attract and retain talent is the key success factor in the industry. If Geely can acquire a company or business unit which has technical advantages and can attract highly qualified technical personnel, it will be able to form core competitiveness. The synergistic effect of strategic M\&A is the result of the formation and spread of core competitiveness.

As the shareholder owning 100 percent of the stock of Volvo, Geely can obtain Volvo's key technology, the use rights of its intellectual property and at the same time stay abreast of Ford's developments. These favorable conditions have a great significance to personnel training and technological upgrading of Geely. Although Volvo's core technology can not be easily obtained, the technical exchange and operation such as production base transfer and adaptive improvement will certainly improve Geely's manufacturing level and design conception remarkably. Taking the advantage of Volvo's automotive safety technique is the key element of Geely's M\&A strategy. In the future, safety performance will be made as one of the core competitiveness of Geely's products.

\section{Analysis of the Mechanism of Synergistic Effect}

\subsection{Management Synergy}

Management synergy refers that the companies use its extensive and efficient management resources through new permutations and combinations after M\&A to improve the existing management and finally increase the revenue. Geely's M\&A of Volvo belongs to horizontal M\&A and its main purpose is to obtain scale effect, basically reflect the management synergy. The mechanism of management synergy can be manifested mainly in the following aspects. First, Geely can make greater use of production capacity and improve production efficiency. Second, through the M\&A of Volvo, Geely can expand scale, thereby increasing the production equipment and the labor force, thus improve the production efficiency. Third, M\&A activities will enable Geely to get part of Volvo's excellent management resources to achieve its learning effect.

\subsection{Operating Synergy}

Operating synergy refers to the improvement of production and operation efficiency of enterprises which caused by economies of scale and economy of scope after M\&A. Through M\&A, Geely's operating synergy can be manifested mainly in the following aspects. First, get some of the market of Volvo, provide special production service to different customer or market, use uniform distribution channels to sell products and save marketing expenses. Second, the fund of Geely will focus on R\&D which can help to further promote the formation of Geely's core competitiveness, launch new product rapidly and form the root causes of synergies.

\subsection{Financial Synergy}

Financial synergy refers to the financial benefits generated by M\&A transaction. It is a net cash flow on benefits which are caused by tax laws, accounting standards and other provisions of the securities and exchange. Since there are differences in the capital structure between Geely and Volvo, this situation may produce the following financial synergy effect. First, according to the tax law, different tax rate should be applied to different types of assets. Geely may achieve a reasonable tax avoidance synergy through M\&A. Second, M\&A may produce the expected effects such as the increase of the stock price and the price-earning ratio [12]. The expected effects have a great influence on M\&A. As the scale of M\&A side are often large, when the acquirement is carried out through share transaction, its price-earnings ratio is often used as the price-earnings ratio of the combined companies after M\&A, which may lead to the increase of stock prices and make the market worth more than the sum of the worth of two companies before M\&A. But in the weak form efficient market, this effect may not occur [13].

The above analysis belongs to the synergistic effect of 
tangible assets. In addition, Geely is also possible to achieve some synergistic effects of intangible assets such as technology synergy, brand synergy and cultural synergy. According to "dynamic synergy" theory, if a company achieves synergistic effect of intangible assets through M\&A, it can get inexhaustible source of competitive advantage.

\section{Evaluation on Synergistic Effect}

Volvo is one of the world's major automobile manufacturers. Currently, as losses year by year, Ford which has a controlling stake in Volvo intends to carry out industrial restructuring and sell the stake of Volvo. In September 2009, Geely participated in the bid for Volvo, and in March 2010, Geely successfully mergered $100 \%$ equity stake of Volvo.

For convenience of the calculation of synergistic effect evaluation, the information assumptions of relevant parameters in the market of Geely and Volvo are as follows: the risk free rate $R_{f}=6 \%$, the expected rate of market $E\left(R_{m}\right)=11 \%$, each company's debt interest rate, $K B=$ $10 \%$, the income tax rate $T=40 \%$, the expected supernormal growth period $n=10$, risk coefficient $\beta_{\text {Geely }}=1.2, \beta_{\text {Volvo }}=1.4$

We select 2009 financial reports published by Geely and Volvo and made analysis on the data which were important and relatively easier to obtain. The following are relevant financial quantitative data of the two companies (see Table 1), for ease of calculation, the data are modified moderately according to the raw data $[14,15]$.

For synergistic effect evaluation, it is necessary to predict the important variables influencing the company value after M\&A. This requires in-depth analysis of each M\&A program according to the evaluation factors. Because there is a strong correlation between the business of Geely and Volvo, considering complementation and promotion of management ability, production technology and marketing channels, Geely's M\&A of Volvo will

Table 1. Relevant financial quantitative data of Geely and Volvo in 2009. (Monetary unit: millions of dollars).

\begin{tabular}{ccc}
\hline \multirow{2}{*}{ Financial index } & \multicolumn{2}{c}{ Company } \\
\cline { 2 - 3 } & Geely & Volvo \\
\hline Debt & 1800 & 24000 \\
Equity capital & 900 & 9000 \\
Total assets & 2700 & 33000 \\
Operating income & 1800 & 12800 \\
Net profit & 1180 & -653 \\
Total market value of capital $(S)$ & 3300 & 1800 \\
\hline
\end{tabular}

Source: financial reports published by Geely and Volvo in 2009 help to develop Geely's new products and improve its profitability. The following estimate values are predicted from the financial data of Geely and Volvo after M\&A, it reflects the results of the above qualitative analysis (see Table 2).

Then we can use the internal model approach to evaluate the M\&A synergistic effect (namely the added value of the combined company after M\&A). The steps of synergistic effect evaluation are as follows.

1) Calculating new $\beta$ value of the combined company.

To simplify the calculation, we assume that the new $\beta$ value $\left(\beta_{G V}\right)$ of the combined company is the weighted average $\beta$ value of each component corporate, then put the new $\beta$ value into capital asset pricing model (CAPM) to obtain the cost of equity capital of the combined company $\left(K S_{G V}\right)$.

$$
\begin{gathered}
\beta_{G V}=\beta_{\text {Geely }} \times \frac{S_{\text {Geely }}}{S_{\text {Geely }}+S_{\text {Volvo }}}+\beta_{\text {Volvo }} \times \frac{S_{\text {Volvo }}}{S_{\text {Geely }}+S_{\text {Volvo }}} \\
K S_{G V}=R_{f}+\left[E\left(R_{m}\right)-R_{f}\right] \times \beta_{G V}
\end{gathered}
$$

According to the known conditions, Table 1, Formulas (1) and (2), we can obtain the result:

$$
\begin{gathered}
\beta_{G V}=1.2 \times \frac{3300}{3300+1800}+1.4 \times \frac{1800}{3300+1800}=1.27 \\
K S_{G V}=6 \%+[11 \%-6 \%] \times 1.27=12.35 \%
\end{gathered}
$$

2) Calculating WACC of the combined company.

According to the known debt interest rate $K B=10 \%$, assume that the rate is unchanging after M\&A, according to the above calculation result of the cost of equity capital, we can obtain the weighted average cost of capital (WACC). We first give the simple balance sheet of the combined company after M\&A (see Table 3).

Then we can calculate the weighted average cost of capital (WACC):

$$
W A C C=K S_{G V} \times \frac{E}{V}+K B \times(1-T) \times \frac{B}{V}
$$

According to Formula (2), we can obtain the result:

$$
\text { WACC }
$$

$$
=12.35 \% \times \frac{9900}{35700}+10 \% \times(1-50 \%) \times \frac{25800}{35700}=7.04 \%
$$

Table 2. Forecast of the key parameters of the combined company of Geely and Volvo.

\begin{tabular}{cccc}
\hline $\begin{array}{c}\text { Financial } \\
\text { index }\end{array}$ & $\begin{array}{c}\text { Net operating income } \\
\text { (millions of dollars) } \\
x_{0}\end{array}$ & $\begin{array}{c}\text { Net investment } \\
\text { rate } \\
b\end{array}$ & $\begin{array}{c}\text { Growth } \\
\text { rate } \\
g_{s}\end{array}$ \\
\hline $\begin{array}{c}\text { Combined } \\
(G V)\end{array}$ & 240 & 0.9 & 0.4 \\
\hline
\end{tabular}


Table 3. Simple balance sheet of the combined company after M\&A. (Monetary unit: millions of dollars).

\begin{tabular}{cc}
\hline Financial index & $\begin{array}{c}\text { combined company } \\
\text { after M\&A(GW) }\end{array}$ \\
\hline Debt $(B)$ & 25800 \\
Equity capital $(E)$ & 9900 \\
Total assets $(V=B+E)$ & 35700 \\
\hline
\end{tabular}

Source: financial reports published by Geely and Volvo in 2009

3) Calculating the value of the combined company.

According to Waston model, we can use the evaluation model of zero growth after supernormal growth period to evaluate the value of the combined company after M\&A, according to the known conditions, the expected supernormal growth period is 10 years. The formula is as follows:

$V_{G V}=x_{0}(1-T)(1-b) \sum_{i=1}^{n} \frac{(1+g s)^{i}}{(1+r)^{i}}+\frac{x_{0}(1-T)(1+g s)^{n+1}}{r(1+r)^{n}}$

According to Formula (3), we can obtain the result:

$$
\begin{aligned}
& V_{G V}=240(1-40 \%)(1-0.9) \sum_{i=1}^{10} \frac{(1+0.4)^{i}}{(1+0.0704)^{i}} \\
& +\frac{500(1-50 \%)(1+0.4)^{11}}{0.0704(1+0.0704)^{10}}=31493
\end{aligned}
$$

According to the above calculation results, we can make simple evaluation on the synergistic effect of the combined company after M\&A (GW) (see Table 4).

From the calculation results we can see that Geely's M\&A of Volvo may generate the value-added (synergistic effect) of 593 million dollars. The M\&A synergistic effect is positive number and meet the basic conditions of M\&A $\left(V_{G V}>V_{\text {Geely }}+V_{\text {Volvo }}\right)$. At the same time, we should consider the realization cost of $\mathrm{M} \& \mathrm{~A}$, which include the M\&A integration costs and pre-acquisition costs. The maximum payment of Geely's M\&A of Volvo is the value-added of synergistic effect subtract the realization costs of M\&A.

The above analysis shows that when Geely make a strategic decision on M\&A, the synergistic effect evaluation on value-added can help decision makers determine the feasibility of different M\&A schemes, thus provide basis for setting price ceiling of M\&A. During the process of evaluation, it is usually required to give reasonable evaluation on the expected return and risk of the combined company in different M\&A schemes. Although we can use historical data as the basis for variable values, we still must predict the earnings, growth and the risk of the combined company according to different M\&A circum-
Table 4. Simple evaluation on synergistic effect. (Monetary unit: millions of dollars).

\begin{tabular}{cc}
\hline Financial index & $\begin{array}{c}\text { combined company } \\
\text { after M\&A(GW) }\end{array}$ \\
\hline Value of combined company & 31493 \\
Less: Debt $(B)$ & 25800 \\
Equity capital after M\&A ( $E$ ) & 5693 \\
Less: Total market value of capital of Geely & 3300 \\
Less: Total market value of capital of Volvo & 1800 \\
Incremental Value(Synergistic effect) & 593 \\
\hline
\end{tabular}

stances. In order to make the prediction more close to reality, it is necessary to give in-depth study of relevant product market and the consequences of organizational merger. But even so, the error of predictive results usually occurs unavoidably and sometimes the margin of error is very large, thus lead to less accurate of the predictive results. Therefore, we should combine with other evaluation methods to predict reasonable synergistic effect gains, so as to provide the scientific basis for information users to make proper strategic M\&A decision.

\section{Risks Analysis of the Realization of Synergistic Effect}

The risks of the realization of synergistic effect refers to the uncertainty of the increment of corporation value and the performance of strategic M\&A. Such risks always exist throughout the whole process of synergistic effect realization. From the view of the root causes of the risks, such risks can be divided into internal risks and external risks, as shown in Figure 3.

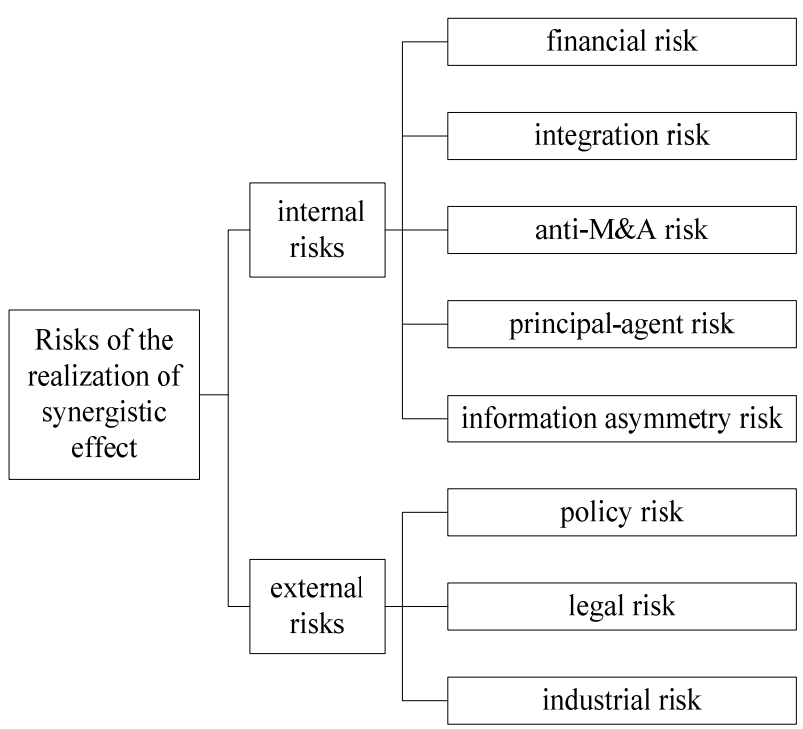

Figure 3. Risks of the realization of synergistic effect. 


\subsection{Internal Risks}

Internal risks mainly refer to the synergistic effect of risks which is caused by M\&A transactions and integration. Synergistic effect of internal risks mainly includes financial risk, integration risk, anti-M\&A risk, principal-agent risk and asymmetric information risk.

\section{1) Financial risk.}

M\&A often requires large amounts of capital, how to raise funds in short term is very important. In this case, Geely can use cash, stock or debt financing for the M\&A. Either way, there are great risks. If Geely use cash to complete the M\&A, there will have the following shortcomings: first of all, a one-time large amount of cash outflow for M\&A will cause intense pressure on the production and management of the enterprise. Second, the trade size will be restricted by the ability to obtain cash and lead to the failure of a large-scale M\&A. Moreover, the merged side may not like cash payment, because they can not get the new company's equity, this situation will also lead to M\&A risks. However, leveraged acquisition is to bear greater risks. Although initially leveraged acquisition can achieve desired economic benefits by paying a small price, but the repayment of debt will give the enterprises serious pressure after M\&A.

According to the mid-year report of Geely in 2009, its total liabilities were 7.0 billion yuan RMB, and the total assets were 13.67 billion yuan RMB, the debt ratio was $51.2 \%$, the liquid capital was 1.88 billion yuan RMB. After financing from Goldman Sachs in the United States, the debt ratio of Geely was as high as $69 \%$, more than the international alert level of $65 \%$. The key to success of Geely's M\&A of Volvo is debt financing. Otherwise, Geely will be heavily in debt and near trouble itself. There are many examples of the bankruptcy of the "advantage" enterprises which could not pay the principal and interest after heavy borrowing.

In order to avoid financial risk, Geely should establish a financial early-warning index system, which include short-term liquidity financial ratios such as liquidity ratio $<2$, quick ratio $<1$, cash ratio $<30 \%$ and long-term liquidity financial ratios such as asset-liability ratio $>60 \%$, time interest earned ratio $<1.5$. In addition, the acquiring company should have plenty of cash flow, make sure that investment can be matched with financing and avoid short-term financing for long-term investment.

2) Integration risk.

According to a survey on the failure of M\&A of Bain \& Company, about $80 \%$ of M\&A failures are caused by enterprise integration failures and only about $20 \%$ appear in the pre-transaction phase of M\&A [16-18]. In this case, the M\&A integration risk of Geely manifested mainly in the following three aspects: first, production and tech- nology can not achieve the expected synergy after M\&A. For example, the M\&A side usually wants to implement diversification through M\&A so as to enter new areas, when the growth of the new areas are faced with obstacles, it often makes M\&A activities in trouble. Second, the integration of personnel, institution and culture after M\&A. If the enterprise can not make effective integration according to the designed M\&A plan, this will lead to the conflict of personnel, institution and cultural between new and old enterprises and resulting in internal friction. Third, the impact of M\&A on business relationships, such as the impact on customers and suppliers. M\&A might cause deterioration in external business relationship and lose some customers and suppliers, thus lead to the increase of enterprise's operating costs and reduction its profitability.

There are great differences in ideology, cultural and social background, thinking mode between China and western countries. Volvo has a series of problems of pension gap and liabilities, apart from these technical problems, cultural conflicts also can not be evaded. Volvo is a luxury automobile brand in Sweden. Swedish trade unions are known as "the world's toughest workers" and "the Northern Europe's most powerful trade unions", whether Geely can lay down reasonable rules and regulations according to the legal and cultural differences between the two countries will be the key to success after the M\&A In early years, some M\&As such as TCL acquired French Thomson in 2004 and BAIC's acquisition of Saab and Opel owned by AM General in 2009 have all been considered to be viable acquisitions, but eventually failed in "integration". Also similar to Lenovo's acquisition of IBM, is still in a difficult cultural integration at present.

In order to avoid integration risk, Geely should first develop comprehensive integration plan to determine how to integrate strategic resources, business processes and core competencies of both sides so as to achieve the strategic objectives of M\&A. Second, in the establishment of new business framework and organizational system, Geely should be committed to the formation of core competitiveness, peel off unrelated or risky businesses. Third, the acquiring company should choose positive, effective communication methods and channels such as communication between the management of both sides, communication between management and employees, communication between the company and other external stakeholders. Four, Geely should pay attention to crossculture management, fully understand cultural background and folkways of the target company, thus to form a new corporate culture through effective integration based on mutual respect and trust.

3) Anti-M\&A risk. 
Under normal circumstances, the merged enterprise's attitude of M\&A is uncooperative. Because the merged enterprises are usually inferior enterprises, they will find ways to stop M\&A. Such practices will greatly increase the M\&A risks [19-22]. In addition, under the modern corporate governance structure, a successful M\&A must first be accepted by enterprise management, then adopted by the board of directors in the enterprise, at last obtain the consent of the large, small and medium-sized investors.

In this case, the original Volvo's manager and technician will probably reject Geely's M\&A, because they might lose the original management position and their vested interests. They might try to prevent the integration after M\&A, thus reduce the synergistic effect and lead to anti-M\&A risk. In addition, if Geely's acquisition offer is accepted by the majority shareholder of Volvo, for instance, there are $40 \%$ of the circulated stockholders who agree on the offer, but some small shareholders are strongly opposed to it and require Geely to raise its offer, such situation may also lead to anti-M\&A risks and reduce the M\&A synergies. Another anti-M\&A case such as Aluminum Corp of China's investment in Australia's third-largest mining company Rio Tinto in 2009. In June 2010, Rio Tinto suddenly renounced the plan of capital injection of 19.5 billion dollars in Aluminum Corp of China and determined to pay rationed shares of 15.2 billion dollars to set up iron ore joint venture with BHP Billiton.

In order to avoid anti-M\&A risk, Geely can adopt the measures of competing for shareholder vote, launching media offensive, placate the trade unions and customers to reduce the resistance of anti-M\&A action of the target company. Furthermore, for possible conflicts of interest, United States, Britain, Hong Kong, Germany, the European Community and other countries and regions place strict limits on anti-takeover measures of the target company. For example, the "Business Judgment Rule" of United States, the "City Code" of Britain and Hong Kong, the "Merger and Acquisition Regulations" of Germany and the 13th Directive of EU Company Law are all include restrictions on the anti-takeover measures of the target company. These restrictions relatively reduce the difficulty of M\&A.

\section{4) Principal-agent risk.}

Currently, the property right of many China's stateowned enterprises is not clear, the appointment and removal of the key management personnel are mainly based on China's administrative structure. For pursuing business expansion, the senior executives with information superiority might ignore the interests of shareholders to meet the needs of their individual fame and fortune. The "out of control" risk of principal-agent relationship in M\&A decision is very dangerous.

As Geely is a listed company, the relationship between its manager and corporate owners is principal-agent relationship. The company management might pursuit company expansion for their own interests to show their performance. They have information superiority and might agreed on the unreasonable terms of the target company without considering its own financial and operating conditions. This conduct will increase the realization cost of synergy and reduced synergy benefits.

In order to avoid principal-agent risk, Geely should first conduct rigorous project selection and establish a scientific feasibility research system. Second, Geely should set up a more complete corporate governance structure and control mechanism, the operators should report accurate and abundant information of M\&A to the board of directors timely and the board of directors should provide effective supervision on the M\&A management layer. Third, the board of directors should offer incentives to the managers and other stakeholders of M\&A, such as linking their income with M\&A effective, presenting them stock options, such measures will encourage them to make a favorable M\&A decision and focus on integrated management of the company after M\&A [23,24].

5) Asymmetric information risk.

In the market mechanism of incomplete competition, the problem of information asymmetry is quite general. During the course of strong company's acquisition of target company, the target company's executives might conceal the facts such as enterprise's hidden losses of contingent liability and the true value of patents to achieve their private intentions. They might also collude with the agency or the insider of the strong enterprise to make false information so that the policy makers of the merging side might make wrong decisions [25]. In this case, due to the global financial crisis, part of the Volvo's clients in the market has been badly hit, the management of Volvo might conceal their hidden losses of liabilities and the true value of intangible assets, thus lead Geely to make wrong decisions.

In order to avoid asymmetric information risk, Geely should forecast synergy reasonably and avoid overpayment. To prevent over-payment, Geely should first optimize company's governance structure and implement a performance management system linked to the reward system, thus to reduce the losses caused by information asymmetry. Second, Geely should invest in stages to reduce the risk, on the one hand, to test the tacit cooperation of the two sides, on the other hand, to disperse risks effectively. Third, the government should play a positive role in M\&A. The government may grant the acquiring company a favorable financial environment and reason- 
able "rules of the game", thus to ensure the standard behavior in investment and interests of the parties [26].

\subsection{External Risks}

As synergistic effect is based on certain of development strategy and the formulation of such a development strategy is based on external environment, therefore, the changes in external environment not only affects the enterprise's development strategy, but also cause the deviation from the expected synergies. The external risks of synergistic effect mainly include policy risk, legal risk and industrial risk.

1) Policy risk.

Policy risk refers to the synergy risk which caused by the adjustment of national economic policies. In particular, during the course of the state-owned enterprises' reform, in some places, there exist the phenomena of regional protectionism which caused by rent-seeking activities of the local governments. Namely, the government develops special policies to protect the vested interests of government and "special groups" or uses administrative means to arbitrarily change its policy to destroy the normal order of market competition, such behavior would increase the risk of synergy. In this case, when Geely makes decision, it should take into account the effect of national economic policy on synergistic effect. At the same time, Geely might set up corresponding subsidiary in Sweden after M\&A, therefore, the Swedish government's policies in the industry can not be ignored.

In order to avoid policy risk, Geely should first understand that which local interest groups have associated with its M\&A. If Geely can rely on the local interest groups to establish lasting relationships, foster the relationship network between different interest groups, it will be able to avoid or reduce the M\&A risk, such as obtain the information on policy changes in advance. Second, strengthening cooperation between the acquiring company and the development banks and other financial institutions of the host country will also help determine the risk of the local situation in the process of M\&A. Third, it's better to sign a M\&A agreement on the rights and obligations with the host government thus to regulate the behaviors of both sides.

2) Legal risk.

Legal risk mainly lies in the following three aspects. The first is the provisions of anti-monopoly law. Most of western countries developed a series of anti-monopoly laws to safeguard fair competition. At present, although there are no corresponding laws promulgated in our country, but when the concentration of the industry increased to a certain level, the relevant legislation is indispensable; the second is the specific provisions of M\&A in the law. For instance, according to the corre- lated laws, if the acquirer holds 5\% of a listed company's shares, it must notice and suspend trading, for each $2 \%$ subsequent increment, it is necessary to repeat the process, if holding $30 \%$ of the shares, it must launch a comprehensive tender offer. This provision leads to great increase of the acquisition costs and M\&A risk. Thirdly, during the course of M\&A, as laws and regulations are incomplete, the conduct of company can not be guided correctly, thus result in the increase of M\&A risk. In this case, Geely's board of directors may face resource integration issues after M\&A such as rehiring new employees and dismissing older employees. In the aspect of dismissal legal system, there are many differences between Swedish and Chinese labor law. From the view of Swedish Labor Court's judicial practice of 70 years, in practice, judges are often biased in favor of the workers in weak position. Therefore, after M\&A, Geely should lay stress on the dismissal of "legitimate reasons" in the legal relationship between employers and employee. In addition, as China's current legal system of M\&A is not perfect, if Geely's legitimate rights and interests are infringed but lack of corresponding legal protection, the synergy risk will increase.

In order to avoid legal risk, Geely should first study the domestic and international laws and policies related to M\&A thoroughly. Second, Geely should engage lawyers, accountants and other professional advisers to participate in the M\&A and formulate the terms of the agreement. Third, use different methods of payment according to the laws of different countries. There are many kinds of M\&A payment, such as cash payment, stock payment, debt payment and comprehensive security payment. In transnational M\&A, stock payment often encounters some legal obstacles. This measure may not minimize the cost of M\&A, but it makes the M\&A feasible.

3) Industrial risk.

Industry risk refers to the uncertainty of the industry prospects caused by the changes of country's economic situation and industrial policy, which might influence the enterprise development strategy. In the process of M\&A decision-making, many enterprises sink into woeful situation because they are not familiar with the new industry they wish to enter or without a accurate grasp of the industry prospects. The "big diving" of e-commerce enterprises in the last two years are good examples.

In order to avoid industrial risk, Geely should consider the development law of industrial life cycle. Currently, China's high-end luxury car is still in the introduction period, Geely may encounter less domestic competitors in this industry. But as the product gradually entering the growth stage of product life cycle, more and more competitors will be attracted to the market and the market position of Geely will be threatened. In addition, in the 
domestic market, automobile is still a luxury, the price elasticity of demand is relatively high, once the macroeconomic situation shows a decline trend, and the profits of Geely in the industry will be greatly reduced. This will definitely increase the M\&A synergy risk .

\section{Conclusions}

With the constant development of market economy, the number and scale of assets reorganization, M\&A and cross-regional joint of Chinese enterprises has been on a rapid rise in recent years. At present, the trend of Chinese enterprises' M\&A has shifted from financial-based M\&A to strategy-based M\&A and shown the following new features: the scale of M\&A has enlarged gradually; strong enterprises are starting to consider M\&A as a business development strategy; share acquisition of listed companies has become an important form of M\&A; M\&A has shown a trend of diversification, securitization and internationalization; M\&A motive has transformed from prevenient simple M\&A based on single motive to strategic M\&A based on industrial integration and expansion $[27,28]$.

International M\&A trends suggest that the main motivation for M\&A is no longer just the pursuit of economies of scale and market price-earnings ratio, but to consolidate the future global economic situation and the strategic position of market competition, namely socalled strategic M\&A. As a developing country in the rising phase, China must size up the situation and achieve synergistic effect through the implementation of strategic M\&A according to her own development needs and thereby enhance the international competitiveness of Chinese enterprises.

\section{REFERENCES}

[1] J. Kitching, “Acquisition in Europe: Causes of Corporate Success and Failure,” Business International, Vol. 2, 1973, pp. 20-35.

[2] S. W. Salant, S. Switzer and R. J. Reynolds, "Losses from Horizontal Mergers: The Effects of an Exogenous Change in Industry Structure on Cournot-Nash Equilibrium," Quarterly Journal of Economecs, Vol. 98, No. 2, 1983, pp. 185-199.

[3] B. J. Cui, "The Characteristics and Thinkings of China’s M\&A,” Enterprise Economy, Vol. 7, 2007, pp. 154-157 (In Chinese).

[4] T. Belcher and L. Nail, "Integration Problems and Turn around Strategies in a Cross Border Merger," International Review of Financial Analysis, Vol. 2, 2000, pp. 219-234.

[5] H. I. Ansoff, “Corporate Strategy,” revised Ed., Penguin Books, London, 1987.

[6] J. H. Dunning, "The Geographical Sources of Compe- titivenss of Firms: Some Results of a New Survey," Transnational corporation, 1996.

[7] M. L. Sirower, "The Synergy Trap: How Companies Lose the Acquisition Game,” Free Press, Mankato, 1997.

[8] Y. M. Du, "The Payment Method of Funds and Risk Prevention of Enterprise,” Commercial Accounting, Vol. 7, 2009, pp. 53-54 (In Chinese).

[9] A. A. Aslani and S. Negassi, "Is Technology Integration the Solution to Biotechnology's Low Research and Development Productivity,” Technovation, Vol. 26, 2006, pp. 573-582.

[10] W. G. Liu, H. P. Hou and C. C. Liu, "Analysis of Technology Transference in Transnational Corporate M \&As," Science of Science and Management of S.\&T., Vol. 8, 2009, pp. 19-23 (In Chinese).

[11] G. Hamel and C. K. Prahalad, "The Core Competence of the Corporation," Harvard Business Review, No. 5-6, 1990, pp. 79-91.

[12] J. X. Li, Y. G. Wang, "Stock Price Effects of M\&A of Listed Companies: Evidence from the Shanghai and Shenzhen Stock Markets of A-Share in China," The Theory and Practice of Finance and Economics, No. 9, 2009, pp. 47-51.

[13] Office of Fair Trading, "Merger Appraisal in Oligopolistic Markets,” Economic Research Paper, 1999. http:// www. oft.gov.uk/business/economic+research/completed.htm

[14] Financial Report of Geely Auto in 2009 [EB/OL]. http:// q.stock.sohu.com/hk.

[15] Financial Report of Volvo in 2009 [EB/OL].volvo group.com/group/china.

[16] L. M. Lucas, "The Role of Culture on Knowledge Transfer: The Case of the Multinational Corporation," Learning Organization, Vol. 13, No. 3, 2006, pp. 257-275.

[17] L. Pepall, D. Richards, G. Normal, "Industrial Organization: Contemporary Theory and Practice,” Cincinnati SouthWestern College Publishing, Cininnati, 1999.

[18] P. H. Mirvis, M. L. Marks, "Managing the Merger,Making IT work," Prentice-Hall, New York, 1992.

[19] E. Eckbo, "Horizontal Mergers, Collusion, And Equilibrium Analysis,” Journal of Financial Economics, No. 11, 1983, pp. 241-273.

[20] R. Stillman, "Examining Antitrust Policy Toward Horizontal Mergers,” Journal of Financial Economics, No. 11, 1983, pp. 225-240.

[21] A. Banerjee and E. W. Eckard, “Are Mega-Mergers Anti -Cmpetitive? Evidence from the First Great Merger Wave,” Radn Journal of Economics, Vol. 29, No. 4, 1998, pp. 803-827.

[22] M. K. Perry and R. H. Porter, "Oligopoly and the Incentive for Horizontal Merger,” American Economic Review, Vol. 75, No. 1, 1985, pp. 219-227.

[23] R. Deneckere and C. Davidson, "Incentives on Form Coalitions with Bertrand Competition," Rand Journal of Economics, Vol. 16, No. 4, 1985, pp. 473-486.

[24] W. B. Su, X. H. Li and Y. Li, "Corporate Control, Information Asymmetry and the Method of Payment for 
Mergers and Acquisitions," Collected Essays on Finance and Economics, No. 9, 2009, pp. 67-73 (In Chinese).

[25] S. Huck, K. Konrad and W. Mueller, "Big Fish Eat Small Fish: On Merger in Stankelberg Markets,” Economics Letters, Vol. 73, No. 2, 2001, pp. 213-217.

[26] A. Creane and C. Davidson, "Multidivisional Firms, Internal Competition and the Merger Paradox,” Canadian
Journal of Economics, Vol. 37, No. 4, 2004, http:// economics.ca /cje /en /forthcoming. php.

[27] T. Nilssen and L. Sorgard, "Sequential Horizontal Mergers," European Economic Review, Vol. 42, No. 9, 1998, pp. 1683-1702.

[28] G. J. Stigler, “Monopoly and Oligopoly by Merger,” The American Economic Review, Vol. 40, No. 2, 1950, pp. 23-34. 